INSIGHTS INTO REGIONAL DEVELOPMENT

ISSN 2669-0195 (online) http://jssidoi.org/IRD/

2021 Volume 3 Number 4 (September)

http://doi.org/10.9770/IRD.2021.3.3(7)
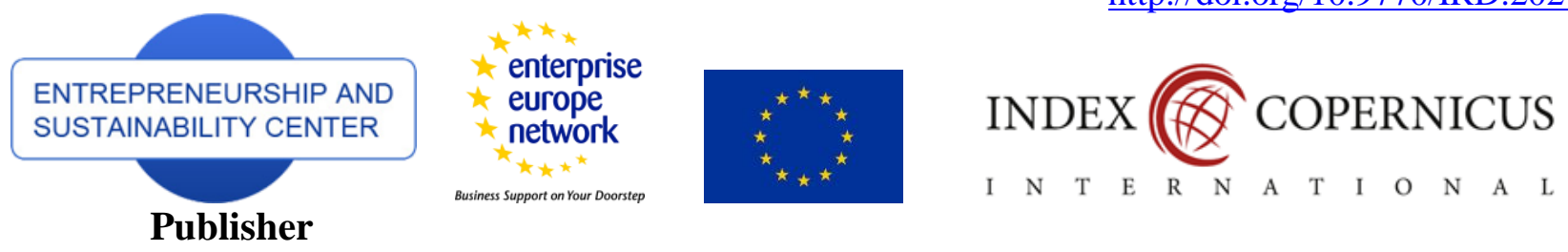

$\begin{array}{llllllllllllll}\text { I } & \mathrm{N} & \mathrm{T} & \mathrm{E} & \mathrm{R} & \mathrm{N} & \mathrm{A} & \mathrm{T} & \mathrm{I} & \mathrm{O} & \mathrm{N} & \mathrm{A} & \mathrm{L}\end{array}$

http://jssidoi.org/esc/home

\title{
AN EMPIRICAL STUDY OF COMMUNITY INVOLVEMENT IN HOUSEHOLD SOLID WASTE MANAGEMENT: A CASE STUDY
}

\author{
Sunday Olutayo Fakunle ${ }^{1}$, Albert Oludele Ajani ${ }^{2}$ \\ ${ }^{1}$ Department of Behavioural Studies, Redeemer's University, Ede, Nigeria \\ ${ }^{2}$ Department of Sociology and Anthropology, Obafemi Awolowo University, Ile-Ife, Nigeria \\ E-mails: ${ }^{1}$ sunnyfak@gmail.com or fakunles@run.edu.ng ; ${ }^{2}$ deleajani@gmail.com
}

Received 15 June 2021; accepted 15 August 2021; published 30 September 2021

\begin{abstract}
In recent times, with the main purpose of enhancing public health, proper management of household solid waste in low-income residential areas of urban centres has gained special attention among scholars in developing countries. From the sociological perspective, perception is one of the key determinants of the people's behaviour in their society. Therefore this study examined the perception of people about solid waste management and identified the key factors influencing this perception. The study was carried out in the first quarters of 2021 and covered Ife Central Local Government Area of Osun State, South-West Nigeria and adopted cross-sectional research design. Purposive sampling method was used to select 5 electoral wards in the Local Government Area where heaps of dirt was more common and 30 households nearer to the heap in each of the wards respectively. The total sample size of 150 used in the study mainly composed the eldest and active female of each the selected household. Descriptive statistics was used to analyze the primary data gathered. This study found that the residents were aware of the health-related challenges resulted from improper management of solid waste and were interested in reducing household solid waste generated. However, methods, the cost, lack of cooperation and nonchalant attitude of people were among the major potential factors militating against achieving this.
\end{abstract}

Keywords: belief; household solid waste management; recycling; public health; awareness

Reference to this paper should be made as follows: Fakunle, S. O., Ajani, O. A. 2021. An empirical study of community involvement in household solid waste management: A case study. Insights into Regional Development, 3(4), 114-127. http://doi.org/10.9770/IRD.2021.3.3(7)

JEL Classifications: Q56

Additional disciplines: sociology, ecology and environment

\section{Introduction}

Insufficiency of the concerted efforts of the international agencies, government and Non-Governmental Organisations (NGOs) to improve the quality of health service delivery is evident in the prevalence of disease in human world. Among the reasons cited for this inadequacy is improper management of household waste (Ajani and Fakunle, 2021b; Olukanni and Nwafor, 2019; Ikebude, 2017; Odewumi, Okeniyi, and Agbede, 2016). For 


\section{INSIGHTS INTO REGIONAL DEVELOPMENT}

ISSN 2669-0195 (online) http://jssidoi.org/jesi/

2021 Volume 3 Number 4 (September)

http://doi.org/10.9770/IRD.2021.3.3(7)

instance, improper disposal of household waste breeds odour, smoke, flies which carry germs, mosquitoes, rats, blockage of drainage resulting in flooding and all these are potential cause of outbreak of several diseases.

In many developing countries, the deplorable condition of urban waste management has made environment the prime concern of scholars, NGOs, government and international organisations. In Nigeria, in particular, among the basic essential services that local authorities render is waste management (Ajani and Fakunle, 2021a; Merem, Twumasi, Wesley, Isokpehi, Fageir, Crisler, Romorno, Hines, Ochai, Leggett and Nwagboso, 2018; Sampson and Ojoye, 2017). This is to ensure improved and sustainable public health; however, this service has not yielded the expected outcome. In many occasions, waste disposal habit of people, corruption, lack of fund, poor work attitude of health workers, inadequate equipment are identified as factors posing challenge to effective waste management (Ebikapade and Baird, 2017; Joshi and Ahmed, 2016; Nabegu and Mustapha, 2015). Among the remedial resolutions, to attain and maintain hygienic environment, that some of these previous studies have suggested is the right perception of people concerning waste management. Therefore, this study focused on examining perception of people towards solid waste management in Ife Central Local Government Area and identifying the potential key factors influencing the perception.

\section{Review of Relevant Literature}

Many urban centers in most developing countries are characterized with geometric increase in population and expansion of commercial activities; these result in uncoordinated environmental set up (Agbaji and EjemotNwadiaro, 2019; Amusan, Akintaro, Osawaru, Makinde, Tunji-Olayeni and Akomolafe, 2018; Ikwuyatum, 2016). Also, Kyessi, Omar and Saria (2017) described the familiar scene in some streets in most of the urban centers as overflowing dumpsters, burning of refuse which pollutes the air and choked drainages. As the waste is not properly managed, flood resulted from disposal of refuse in drainages and waterways; outbreak of diseases such as cholera, malaria and other sanitation related ailments is eminent.

Environmental hazards and health risks associated with improper solid waste management are generated as indiscriminate disposal of refuse is unrestrained and this poses threats to public health in general. Scholars have further highlighted the consequences of improper solid waste management and these include much pressure on the available health facilities resulted from treating the contacted communicable diseases (Ajani and Fakunle, 2021b; Ogunniran, 2019), cost of repairing the infrastructure damaged through flooding (Salami, Adegbite, Bademosi, Lawal, Olutayo and Olowosokedile, 2018; Stanley and Owhor, 2018), cost of drugs to treat victims of ailment (Aliyu and Amdu, 2017), and environmental degradation (Ajani and Fakunle, 2021a; Karshima, 2016). All these resulted from negligence on the part of residents to deal with waste as a priority issue in society. Among the challenges militating against municipal waste management in many developing countries are poor disposal technique, poor storage facilities, negligence and poor attitude of people towards solid waste management (Emelumadu, Azubike, Nnebue, Azubike and Sidney-Nnebue, 2016).

Moreover, scholars have established that socio-cultural factors significantly affect land use pattern concerning solid waste disposal in developing countries (Ajani and Fakunle, 2021a; Khan, Kumar and Samadder, 2016). For instance, Obiora and Tochukwu (2019) as well as Onuminya and Nze (2017) found that solid waste accumulation is a product of chaotic land use pattern while the number of household living and eating habit in a house considerably determine the level and composition of refuse to be generated. Efforts to control improper disposal of household solid waste has prompted some studies to suggest enforcement of waste management legislation, proper policy and planning framework for waste management (Oyedotun, Kasim, Famewo, Oyedotun, Moonsammy, Ally and Renn-Moonsammy, 2020; Maiyaki, Marzuki and Ahmed, 2019; Nabegu and Naibbi, 2017; Nabegu and Mustapha, 2015). Studies have also proposed that regular waste audits tend to facilitate waste reduction, participation in waste management and environmental sanitation (Popoola, Ayangbile and Adeleye, 2016; Rigasa, Badamasi, Galadimawa and Abubakar, 2016; Kawai and Tasaki, 2016). Moreover, Winter and 


\section{INSIGHTS INTO REGIONAL DEVELOPMENT}

ISSN 2669-0195 (online) http://jssidoi.org/jesi/

2021 Volume 3 Number 4 (September)

http://doi.org/10.9770/IRD.2021.3.3(7)

Ujoh (2020) adduced introducing significant regulation to people as another strategy to achieve solid waste management. The regulation in most instances covers introducing stern restrictions and bans on indiscriminate dumping of refuse.

Some other studies, however, found that the cost of implementing most of these policies in many developing countries has constituted a limitation (Ayantoyinbo and Adepoju, 2018; Hammed, Sridhar and Wahab, 2016; Soukopova, Struk and Hrebicek, 2016). Total avoidance of waste is another concept introduced to maintain sustainable environmental sanitation (Song and Zeng, 2015). The concept seeks to absolutely prevent solid waste to replace waste management. The philosophy of zero waste is eliminating waste from the outset of the product. Therefore, the concept concerns the industrial production process more than the household.

Also, a number of studies have asserted that creating partnership and generating joints efforts among the households, private and public sectors to manage the household generated solid waste is a veritable springboard to achieve hygienic environment (Olukanni and Nwafor, 2019; Chopra and Kapoor, 2016; Nabukeera, 2016; Opoko and Oluwatayo, 2016). However, these studies also highlighted several challenges inherent in this partnership, and these include, the bureaucratic processes that private sectors have to undergo before they are legally accepted for their services, the financial capacity of the private sectors in limited and this hampers the quality of their service delivery, limited level of technical know-how, poor receptivity of the services of the private sectors that are involved in municipal waste management by the households and the cost in part of the household to access the service. The highlighted factors that incapacitate the private sectors involved in waste management and the reality have indicated the inadequacy of the partnership.

Adeniran, Nubi and Adelopo (2017) as well as Gallardo, Edo-Alcon, Carlos, and Renau, (2016) suggested waste characterization as another means of achieving proper management of waste. According to these scholars, was characterization enhances waste separation for recycling and devising the most suitable means of managing the non-recyclable waste. However, these scholars indicated that the majority of the households in Nigeria are yet to participate in waste characterization. Hence, studies have intensified the key role of education to encourage public participation in solid waste management (Fagbemi, Ogungbemi, Philips, Obatuase and Hassan, 2020; Chow, So, Cheung and Yeung, 2017). Awareness can be further created through trainings, competitions and compensations, programmes and advertisement as information and education are vital tools for behavioural shift and gaining public support for waste management initiatives (Abila and Kantola, 2017; Ferronato, Torretta, Ragazzi and Rada, 2017). Educational campaign is also envisaged to foster support and motivation for solid waste management. Raising awareness about different waste management programs is envisaged to have positive effects. Also, proper education and public awareness at the grassroots level were also suggested to enhance management of solid waste as these were expected to generate environmental concern and formation of groups to safeguard environment (Sinthumule and Mkumbuzi, 2019; Muhammad, Sik, Johar and Sabri, 2016). In addition, studies have identified right perception of people towards waste management as a costless way of managing solid waste and the primary mechanism to promote public health. For instance, enlightenment of people on indiscriminate littering of solid waste, source reduction activities, promoting recycling, open dumping and discharge of garbage into drains in streets is envisaged to reduce improper solid waste management and translate to a significant reduction in the outbreak of communicable diseases (Ajani and Fakunle, 2021; Oyedotun et al., 2020).

Studies abound in solid waste management. Most of these studies were carried out at macro level, investigating role of governments, NGOs and community as a whole on municipal sanitation (Olukanni and Oresanya, 2018; Mbah and Nzeadibe, 2017; Sridhar, Jegede, Oluborode and Uwadiegwu, 2017; Ogunba, 2016). However, not sizeable proportion of the few studies carried out on this phenomenon at micro or individual level considered perception of people towards solid waste management in particular in Ife Central Local Government Area, while the inference from Ajani and Fakunle (2021a), Adeniran, Nubi and Adelopo (2017) as well as Olukanni and Aremu (2017), from one perspective, also advocated an empirical study such as this; these account for the novelty 


\section{INSIGHTS INTO REGIONAL DEVELOPMENT}

ISSN 2669-0195 (online) http://jssidoi.org/jesi/

2021 Volume 3 Number 4 (September)

http://doi.org/10.9770/IRD.2021.3.3(7)

value of this study. Therefore, this study was carried out to examine perception of each household towards solid waste management and to identify the potential factors influencing the perception in Ife Central Local Government Area of Osun State, Nigeria.

\section{Methodology}

The study location was Ife Central Local Government Area of Osun State, South-West Nigeria. The current study adopted cross-sectional research design. Multi-stage sampling method was used; the study location was divided into 11 sections according to the existing electoral wards from which 5 wards where heaps of dirt were more common were purposively selected. Also, purposive sampling technique was used to select 30 households nearer to the heap in each of the 5 wards making a total sample size of 150 . The sample size mainly composed the eldest and active female of each the selected household because the current study considered them to be actively involved in solid waste disposal and management. However, where female eldest was not available, their male counterparts were employed. The primary data needed was gathered using questionnaire which consisted of both structured questions and unstructured questions to explore the objective of the study. All the distributed copies of the questionnaire were properly monitored to ensure the empirical validity of this study and to avoid loss of any of the copies

\section{The study findings}

The current study involved both gender. However, the study purposively employed more women (70 per cent) than men (30 per cent); this was because the study considered women to be more actively involved in solid waste disposal and management than men. Majority (75 per cent) of the respondents were within the age bracket of 4049 while 15 per cent and 10 per cent of the respondents were between the age groups of 50-59 and 30-39 respectively. The age compositions of the respondents of the current study indicated that the respondents were still active in decision making on household solid waste disposal management. This information is presented in Table 1 below.

Table 1. Presenting age and gender distribution of the respondents

\begin{tabular}{|c|c|}
\hline Socio-economic status & Percentages \\
\hline Gender distribution & 30.0 \\
Male & 70.0 \\
Female & 100 \\
Total & \\
& 10.6 \\
Age-group distribution & 75.1 \\
30-39 years & 14.3 \\
40-49 years & 100 \\
50 years and above & \\
Total & \\
\multicolumn{2}{|c|}{ Source: Authors' field survey (2021) }
\end{tabular}

Also, a large proportion (62 per cent) of the respondents was married and living with their spouses, while 20 per cent were not living with their spouses. Almost 15 per cent of the respondents were widow or widower and only 2 per cent were single. The marital composition also indicated that most of the respondents involved in the current study respectively belonged to a household that contained at least two people, and this most likely translated to generating more solid waste than those that were single. Moreover, the current study considered levels of formal education of the respondents, for it is envisaged in this study that having formal education encourages proper management of household solid waste. Data showed that majority (50 per cent) of the respondents had tertiary education. While about 28 per cent and 15 per cent of the people completed their secondary education and primary education respectively, also, almost 4 per cent had incomplete secondary school education, 2 per cent had 
no formal education and 1 per cento $f$ the people were unable to complete their primary education. In light of the occupation of the respondents, almost 45 per cent of them were self-employed while 29 per cent and 26 per cent were respectively working in public sectors and private sectors. The table 2 below presents this information.

Table 2. Presenting the marital status, highest education levels religion and employers of the respondents

\begin{tabular}{|c|c|}
\hline Socio-economic status & Percentages \\
\hline Marital status & 2.3 \\
Single & 61.7 \\
Married & 20.4 \\
Divorced & 14.6 \\
Widow & 100 \\
Total & \\
& \\
Highest level of educational status & 1.6 \\
No schooling & 1.4 \\
Primary incomplete & 15.2 \\
Primary completed & 3.8 \\
Secondary incomplete & 28.3 \\
Secondary completed & 49.7 \\
Post secondary & 100 \\
Total & \\
Employer & 28.8 \\
Public sector & 26.5 \\
Private sector & 44.7 \\
Self-employed & 100 \\
Total & \\
Source: Authors' field survey (2021) & \\
\hline
\end{tabular}

Findings indicated that 80 per cent of the residents under the study were aware of the health-related challenges and communicable diseases resulted from improper management of household solid waste. Also, majority (75 per cent) of the residents considered that improper disposal of household solid waste has adverse effects on the public as a whole, in particular, on people living closer to where there is heaps of solid waste while 16 per cent of the people has a contrary opinion as 9 per cent of residents under this study were unable to decide the effect.. This might also lend credence to the educational levels of the larger percentage of the respondents in one part. Moreover, the role of Nigerian government through National Orientation Agency (NOA) by enlightening the mass through the mass media on the consequences of improper management of solid waste might be felt in this sense.

Studies have suggested reduction of the quantity of solid waste as a means maintaining environmental sanitation (Abbasi, 2018; Sampson and Ojoye, 2017; Adekomaya and Ojo, 2016; Song, et al., 2015). Data generated in the current study showed that majority (67 per cent) of the respondents was interested in reduction of the quantity of the household solid waste generated. However, the study discovered that most of the residents (70 per cent) were yet to devise the means to reduce the household waste generated. Also, the cost involved in the process of reduction amounts to inability to actualize the quantity reduction. The Table 3 below presents the parameters, statement and opinions of the people under study. 
INSIGHTS INTO REGIONAL DEVELOPMENT

ISSN 2669-0195 (online) http://jssidoi.org/jesi/

2021 Volume 3 Number 4 (September)

http://doi.org/10.9770/IRD.2021.3.3(7)

Table 3. Presenting households' perception of managing their solid waste management

\begin{tabular}{|c|c|c|c|c|c|c|c|}
\hline & Parameters & \multicolumn{6}{|c|}{ Responses in percentages } \\
\hline $\mathbf{s} / \mathbf{n}$ & Statements & $\begin{array}{c}\text { Strongly } \\
\text { agree }\end{array}$ & Agree & Disagree & $\begin{array}{l}\text { Strongly } \\
\text { disagree }\end{array}$ & Undecided & Total \\
\hline 1. & $\begin{array}{l}\text { I am aware of the } \\
\text { health-related } \\
\text { challenges and } \\
\text { communicable } \\
\text { diseases resulted } \\
\text { from improper } \\
\text { management of } \\
\text { household solid } \\
\text { waste }\end{array}$ & 55.6 & 24.4 & 9.1 & 5.2 & 5.7 & 100 \\
\hline 2. & $\begin{array}{l}\text { Improper disposal } \\
\text { of household solid } \\
\text { waste has adverse } \\
\text { effects on public } \\
\text { health }\end{array}$ & 54.6 & 20.4 & 10.2 & 5.8 & 9.0 & 100 \\
\hline 3. & $\begin{array}{l}\text { I am interested in } \\
\text { reduction of the } \\
\text { quantity of the solid } \\
\text { waste my household } \\
\text { generates }\end{array}$ & 56.5 & 13.5 & 15.2 & 10.3 & 4.5 & 100 \\
\hline 4. & $\begin{array}{l}\text { In my household, } \\
\text { we have devised } \\
\text { means of reducing } \\
\text { the solid waste we } \\
\text { generate }\end{array}$ & 0.5 & 5.5 & 35.2 & 45.0 & 13.8 & 100 \\
\hline
\end{tabular}

Source: Authors' field survey (2021)

Moreover, this study considered the main method the households in the study area adopted to manage the solid waste they generated. The data collected showed that most ( 90 per cent) of the households in the study area resorted to burning of solid refuse as the main method of managing household generated solid waste. About 5 per cent and 3 per cent employed the services of wastes collectors and utilized legal dumpsites as the main method of waste disposal respectively, while almost 2 per cent of the people mainly utilized recycling method. Moreover, as presented in the Table 4 below, the data indicated that waste to energy is yet to be popularly accepted in the study location.

Table 4. Presenting the main method adopted to manage household generated solid wastes

\begin{tabular}{|c|c|c|c|c|c|c|}
\hline $\begin{array}{c}\text { Main method } \\
\text { of solid waste } \\
\text { management } \\
\text { adopted }\end{array}$ & Recycling & Legal dumpsites & Burning & $\begin{array}{c}\text { Waste collector's } \\
\text { service }\end{array}$ & Waste to energy & Total \\
\hline $\begin{array}{c}\text { Percentage of } \\
\text { the people } \\
\text { involved }\end{array}$ & 1.9 & 3.2 & 89.6 & 4.8 & 0.5 & 100 \\
\hline
\end{tabular}

Source: Authors' field survey (2021)

Also, this study considered the awareness of the residents of the environmental implications of burning refuse. Data indicated that a larger percentage (90 per cent) of them were aware of the implications, via the unstructured questions in the tool utilized to collect the data for this study, the people cited burning as the cheapest means of household solid waste management known to them as the main reason for their wide acceptance of the method. On awareness of the respondents about recycling of some solid waste such as nylon, plastic, iron and aluminum materials, among others, findings showed that about 77 per cent of the respondents were aware while almost 23 per cent were not aware of this process. The large proportion of the respondents that were aware of this process 
INSIGHTS INTO REGIONAL DEVELOPMENT

ISSN 2669-0195 (online) http://jssidoi.org/jesi/

2021 Volume 3 Number 4 (September)

http://doi.org/10.9770/IRD.2021.3.3(7)

lend credence to reality that majority of the respondents had tertiary education as the bivariate analysis of data also indicated.

Suffice to add that the current study considered that being aware of recycling process is not tantamount to practicing the process. Therefore, data indicated that majority ( 85 per cent) of the respondents was yet to be involved in the recycling process while only 15 per cent have been practicing the process. One significant factor the current study found, via unstructured questions in the data collection tool, as a challenge to practicing the recycling process among the residents was that majority of them considered the procedure of the recycling process as disparaging and time wasting.

Government at different levels in Nigeria has launched several programmes to enhance environmental sanitation in the country. This endeavour is evident in formulation of laws on sanitation; the introduction of War Against Indiscipline (WAI) at the federal level and provision of trucks for collection of solid waste by the government of many states. On the residents' awareness of any residential area law concerning management and proper disposal of solid waste in their location, finding showed that majority (68 per cent) of the residents were aware of the law while 32 per cent were not aware. Also, via the unstructured questions in the tool for study data collection, the current study discovered that the law requiring each household to pay a solid waste user charge was the only law existed in the study location. The law was made by the landlord association to employed cleaners. However, findings indicated that the law was no longer effective as economy condition and lack of cooperation among the residents were mostly cited as the factor responsible for this. The Table 5 below presents this information.

Table 5. Presenting households' perception of managing their solid waste management

\begin{tabular}{|c|c|c|c|c|c|c|c|}
\hline & Parameters & & & Response & percentage & & \\
\hline $\mathrm{s} / \mathrm{n}$ & Statements & $\begin{array}{c}\text { Strongly } \\
\text { agree }\end{array}$ & Agree & Disagree & $\begin{array}{l}\text { Strongly } \\
\text { disagree }\end{array}$ & Undecided & Total \\
\hline 1. & $\begin{array}{c}\text { I am aware of the } \\
\text { environmental } \\
\text { implications of } \\
\text { burning as a method } \\
\text { managing } \\
\text { household solid } \\
\text { waste }\end{array}$ & 67.3 & 22.7 & 2.6 & 5.3 & 2.1 & 100 \\
\hline 2. & $\begin{array}{c}\text { I am aware of } \\
\text { recycling of some } \\
\text { common household } \\
\text { solid waste e.g. } \\
\text { nylon, plastic, iron } \\
\text { \& aluminum } \\
\text { materials } \\
\end{array}$ & 46.7 & 30.3 & 14.6 & 8.4 & 0.0 & 100 \\
\hline 3. & $\begin{array}{l}\text { Recycling might not } \\
\text { be the main method } \\
\text { of waste } \\
\text { management for me } \\
\text { but I still use it }\end{array}$ & 4.6 & 10.4 & 27.7 & 57.3 & 0.0 & 100 \\
\hline 4. & $\begin{array}{l}\text { I am aware of the } \\
\text { existence of the } \\
\text { laws in my area } \\
\text { concerning proper } \\
\text { management of } \\
\text { household wastes }\end{array}$ & 35.7 & 32.3 & 22.4 & 9.6 & 0.0 & 100 \\
\hline
\end{tabular}

Source: Authors' field survey (2021) 
INSIGHTS INTO REGIONAL DEVELOPMENT

ISSN 2669-0195 (online) http://jssidoi.org/jesi/

2021 Volume 3 Number 4 (September)

http://doi.org/10.9770/IRD.2021.3.3(7)

The current study uncovered some potential factors that influenced the perception of the residents concerning household solid waste management. Data showed that most ( 83 per cent) of the residents cited less financial provision as one the challenges they faced. This finding confirmed the authenticity of the economy condition earlier cited in the current study as a factor militating against the implementation of the only residential law on sanitation existing in the study location. However, about 14 per cent of the residents rejected this factor and were unconcerned respectively. Another factor considered in the study was nonchalant attitude of people towards proper solid waste management. Finding indicated that most ( 81 per cent) of the residents under the study accepted that nonchalant attitude of the residents significantly contributed to the present indiscriminate dumping in the study location.

Also, the current study considered poor understanding of household solid waste management as another factor. This study found that almost 78 per cent of the respondents indicated that people in the study location needed orientation on proper management of the solid waste generated. Moreover, majority ( 88 per cent) of the respondents identified absence of public waste bins in the area as another reason for poor household waste management. Availability of those bins was envisaged to facilitate proper disposal of waste and keeping the environment clean.

Table 6. Presenting key factors influencing perception of managing their solid waste management

\begin{tabular}{|c|c|c|c|c|c|c|c|}
\hline & Parameters & & & Response & percentage & & \\
\hline $\mathrm{s} / \mathrm{n}$ & Statements & $\begin{array}{c}\text { Strongly } \\
\text { agree }\end{array}$ & Agree & Disagree & $\begin{array}{l}\text { Strongly } \\
\text { disagree }\end{array}$ & Undecided & Total \\
\hline 1. & $\begin{array}{l}\text { The cost involved in } \\
\text { proper management } \\
\text { of household waste } \\
\text { is the major } \\
\text { constraint I have }\end{array}$ & 66.7 & 16.3 & 7.4 & 7.0 & 2.6 & 100 \\
\hline 2. & $\begin{array}{c}\text { Nonchalant attitude } \\
\text { of people towards } \\
\text { proper management } \\
\text { of household waste } \\
\text { contributes to poor } \\
\text { hygienic condition } \\
\text { of my residential } \\
\text { area }\end{array}$ & 47.4 & 33.6 & 11.3 & 3.4 & 4.3 & 100 \\
\hline 3. & $\begin{array}{c}\text { People in my } \\
\text { residential area lack } \\
\text { adequate knowledge } \\
\text { about proper way to } \\
\text { manage household } \\
\text { generated wastes }\end{array}$ & 44.0 & 34.2 & 12.6 & 5.2 & 4.0 & 100 \\
\hline 4. & $\begin{array}{l}\text { Absence of waste } \\
\text { public waste bins } \\
\text { contributes to poor } \\
\text { management of the } \\
\text { generated household } \\
\text { solid waste in my } \\
\text { residential area }\end{array}$ & 40.5 & 48.3 & 6.4 & 2.6 & 2.2 & 100 \\
\hline 5. & $\begin{array}{l}\text { There is at least a } \\
\text { refuse bin use by } \\
\text { my household }\end{array}$ & 34.2 & 43.5 & 9.5 & 12.8 & 0.0 & 100 \\
\hline
\end{tabular}

Source: Authors' field survey (2021) 


\section{INSIGHTS INTO REGIONAL DEVELOPMENT}

ISSN 2669-0195 (online) http://jssidoi.org/jesi/

2021 Volume 3 Number 4 (September)

http://doi.org/10.9770/IRD.2021.3.3(7)

The current study further examined availability of bins in each house in the study location and found that almost 78 per cent of the household under the study had no refuse bin, responses to the unstructured questions in the data collection tools indicated that the majority of the residents could not find any genuine reason to own refuse bins. Findings indicated that most of the household made use of illegal dumpsites, open space available, burning, drainages when it is raining, to get rid of the household solid waste whether bio-degradable or non-biodegradable. The Table 6 above presents this information.

\section{Discussion of Findings}

Studies have emphasized the importance of public participation, environmental education, enlightened debates and public awareness to enhance environmental quality (Ajani and Fakunle, 2021b; Chopra and Kapoor, 2016; Nabukeera, 2016). The findings of the current study on awareness of the health-related challenges and communicable diseases resulted from improper management of solid waste accentuate the role of enlightenment of the mass. The current study also supported previous studies that suggested reduction of the quantity of solid waste as a means maintaining environmental sanitation (Sampson and Ojoye, 2017; Song et al., 2015) as most of the respondents were found interested in reduction of the quantity of the household solid waste generated. However, the current study is in line with the finding of Song, et al. (2015) that many people were yet to devise the means to reduce the household waste generated. The cost involved in the process of reduction was found amounted to inability to actualize the quantity reduction in the current study.

Studies abound on recycling of some solid waste to enhance waste management (Ikube, 2017; Kyessi et al., 2017). The current study confirmed that many people, in particular among the educated, were aware of the recycling process. However, some residents were not aware of this process and this supported Obiora, et al. (2019) that advocated perpetual enlightenment on recycling process, in particular, in the rural areas. Findings of the current study indicated that majority of the residents were not practicing the recycling process despite that majority of the resident were aware of recycling process. Moreover, time wasting was one challenge the current study discovered militating against practicing recycling process.

The current study found that people have taken steps to informally formulate a residential law concerning management and proper disposal of solid waste among themselves. This finding supported the recommendation of making laws to inhibit people from indiscriminate disposal of solid waste (Nabegu and Naibbi, 2017; Nabegu and Mustapha, 2015). However, the efficacy of any law depends on its applicability and the cost involved in its application (Winter and Ujoh, 2020), this study found less financial provision as one challenge to the application of this law as the law was requiring each household to pay a solid waste user charge.

The current study is in tandem with study of Chopra and Kapoor (2016) and Nabukeera (2016) that emphasized cooperation and social cohesion among people to achieve sustainable environmental sanitation management as findings indicated that the law was no longer effective as lack of cooperation among the residents was also cited responsible. On the potential factors that influenced the perception of people concerning household solid waste management, the current study supported the findings of Khan, Kumar and Samadder (2016) that socio-economic factors significantly affect people's perception about waste management. Studies including the current study have found that nonchalant attitude poor understanding of people towards proper solid waste management significantly pose threats to achieving sustainable environmental sanitation and enhancement of public health (Maskey, 2018). These findings advocate orientation on proper management of the solid waste generated among people.

Provision of materials to facilitate sustainable management of household solid waste is needed as the current study identified absence of public waste bins in the area as another reason for poor household waste management. This finding is in line with the assertion that availability of trucks, public bins and designed dumpsite facilitates proper disposal of waste and keeping the environment clean (Naibbi and Umar, 2017; Sampson and Ojoye, 2017; 


\section{INSIGHTS INTO REGIONAL DEVELOPMENT}

ISSN 2669-0195 (online) http://jssidoi.org/jesi/

2021 Volume 3 Number 4 (September)

http://doi.org/10.9770/IRD.2021.3.3(7)

Abimbola, Molemodile, Okonkwo, Negin, Jan and Martiniuk, 2016; Adeniran and Oyemade, 2016; Nnaji, C. C. (2015).

Studies abound in converting (household) waste to a source of energy (Abbasi, 2018; Ogunjuyigbe, Ayodele and Alao, 2017; Somorin, Adesola, and Kolawole, 2017; Adekomaya and Ojo, 2016). Moreover, scholars have presented (household) waste conversion to energy as a form of attaining zero waste in the contemporary period (Akuru, Onukwube, Okoro and Obe, 2017; Aliyu, Dada and Adam, 2015). However, this current study established that the idea of waste to energy is yet to be popularly accepted in the study location and the reasons cited for the low acceptance poor perception of the idea, lack of technical know-how, the cost involved and nonchalant attitude of the residents towards the idea; these results are in line with Rominiyi, Fapetu, Owolabi, and Adaramola, (2017) and Tsunatu, Tickson, Sam, Namo (2015).

\section{Conclusions and prospects for future research}

The current study concluded that residents of Ife Central Local Government were aware of the health-related challenges resulted from improper management of solid waste. Also, the residents were interested in reducing household solid waste generated, recycling process and solid waste management in general. However, methods, the cost, lack of cooperation and nonchalant attitude of people were potential factors militating against achieving this. Hence, this study advocates orientation on proper management of the household solid waste generated, strict implementation of law on sanitation, provision of materials such as refuse bins and trucks to facilitate sustainable management. A more detailed, nation-widespread and empirical research on perception of people towards household solid waste management was also suggested.

\section{References}

Abbasi, S. A. 2018. The myth and the reality of energy recovery from municipal solid waste. Energy, Sustainability and Society, 8(36), 115. https://doi.org/https://doi,org/10.1186/s13705-018-0175-y

Abila, B. and Kantola, J. 2017. Proposed solutions in municipal solid-waste management. International Journal of Environment and Waste Management, 19(4), 297-317.

Abimbola, S., Molemodile, S. K., Okonkwo, O. A., Negin, J., Jan, S. and Martiniuk, A. L. 2016. The government cannot do it all alone: Realist analysis of the minutes of community health committee meetings in Nigeria, Health Policy and Planning, 31, 332-345. doi:10.1093/heapol/czv066. http://heapol.oxfordjournals.org

Adekomaya, O. and Ojo, K. 2016. Adaptation of plastic waste to energy development in Lagos: an overview assessment. Nigerian Journal of Technology (NIJOTECH), 35(2), 778-784. http://dx.doi.org/10.4314/njt.v35i1.12

Adeniran, A. E., Nubi, A. T. and Adelopo, A. O. 2017. Solid waste generation and characterization in the University of Lagos for a sustainable waste management. Waste Management, 67, 3-10. https://doi.org/10.1016/j.wasman.2017.05.002

Adeniran, A. O. and Oyemade, H. 2016. Inventory analysis of solid waste management in Ikorodu community. Civil and Environmental Research, 8(9), 26-38.

Agbaji, D. D. and Ejemot-Nwadiaro, R. I. 2019. Solid waste management in Calabar metropolis: Case study of Calabar urban development authority (2008 - 2017). Greener Journal of Medical Sciences, 9(1), 17-31. http://doi.org/10.15580/GJMS.2019.1.032919058

Ajani O. A. and Fakunle S. O. 2021a. Cultural dimension of environmental problems: a critical overview of waste generation and management in Nigeria, American International Journal of Multidisciplinary Scientific Research, 8(1), 1-15. https://doi.org/10.46281/aijmsr.v8i1.1110 


\section{INSIGHTS INTO REGIONAL DEVELOPMENT}

ISSN 2669-0195 (online) http://jssidoi.org/jesi/

2021 Volume 3 Number 4 (September)

http://doi.org/10.9770/IRD.2021.3.3(7)

Ajani, O. A. and Fakunle, S. O. 2021b. Community participation: the cornerstone for the efficiency of institutional frameworks for household solid waste management in low income residential areas in Nigeria. American International Journal of Supply Chain Management, 2(1), 37-45. https://doi.org/10.46545/aijscm.v2i1.327

Akuru, U. B., Onukwube, I. E., Okoro, O. I. and Obe, E. S. 2017. Towards 100 percent renewable energy in Nigeria. Renewable and Sustainable Energy Reviews, 71, 943-953.

Aliyu, A. and Amdu, L. 2017. Urbanization, cities and health: the challenges to Nigeria- A review. Annals of African Medicine, 16(4), 149158

Aliyu, A. S., Dada, J. O. and Adam, I. K. 2015. Current status and future prospects of renewable energy in Nigeria. Renewable and Sustainable Energy Reviews; 48(0), 336-346.

Amusan, L., Akintaro, H., Osawaru, F., Makinde, A., Tunji-Olayeni, P. and Akomolafe M. 2018. Information on state of challenges of waste management system in Nigeria urban housing system. International Journal of Mechanical and Production Engineering Research and Development (IJMPERD), 8(2), 75-86. https://doi.org/10.24247/ijmperdapr20188

Ayantoyinbo, B. and Adepoju, O. 2018. Analysis of solid waste management logistics and its attendant challenges in Lagos metropolis. Logistics, 18(2), 11. https://doi.org/10.3390/logistics20200110ECD/SWAC

Chopra, A. and Kapoor, D. R. 2016. Study of public private partnership in urban solid waste management. International Journal of Engineering Trends and Technology (IJETT), 40(1), 35-37.

Chow, C. F., So, W. M., Cheung, T. Y. and Yeung, S. K. D. 2017. Plastic waste problem and education for plastic waste management. The Newsletter of The East-Asian Association for Science Education, 8(1), 125-140. https://doi.org/10.1007/978-981-10-3344-5_8

Ebikapade A. and Baird, J. 2017. Solid Waste Management Trends in Nigeria. British Journal of Environmental Sciences, 5(6), 25-37. www.eajournals.org

Emelumadu, O. F., Azubike, O. C., Nnebue, C. C. F. Azubike, N. and Sidney-Nnebue, Q. N. 2016. Practice, pattern and challenges of solid waste management in Onitsha metropolis, Nigeria. American Journal of Public Health Research 4(1), 16-22.

Fagbemi, K. B., Ogungbemi, A. O., Philips, O. O., Obatuase, B. and Hassan, Y. O. 2020. Users' perception of environmental sanitation exercise in selected market in Nigeria cities. International Journal of Waste Resources, 10(378), 1-4. https://doi.org/10.35248/22525211.20.10.378

Ferronato, N., Torretta, V., Ragazzi, M. and Rada, E. C. 2017. Waste mismanagement in developing countries: a case study of environmental contamination. UPB Sci. Bull., 17(79), 185-196.

Gallardo, A., Edo-Alcon, N., Carlos, M. and Renau, M. 2016. The determination of waste generation and composition as an essential tool to improve the waste management plan of a University. Waste Management, 53, 3-11. https://doi.org/10.1016/j.wasman.2016.04.013

Hammed, T. B., Sridhar, M. K. C. and Wahab, B. 2016. Enhancing Solid Waste Collection and Transportation for Sustainable Development in the Ibadan Metropolis, Nigeria. European Journal of Research in Social Sciences, 4(7), 23-32.

Ikebude, C. F. 2017. Feasibility study on solid waste management in Port-Harcourt metropolis: causes, effects and possible solutions. Niger. J. Technol. 2017(36), 276-281. https://doi.org/10.4314/njt.v36i1.33

Ikwuyatum, G. 2016. Migration and urbanization: Exploring the factors of the nexus in Nigeria. International Journal of Humanities and Social Sciences, 6(8), 161-175.

Joshi, R. and Ahmed, S. 2016. Status and challenges of municipal solid waste management in India: A review. Cogent Environmental Science, 28(1), 1-18. https://doi.org/10.1080/2 3311843.2016.1139434

Karshima, S. N. 2016. Public health implications for poor municipal waste management in Nigeria. Journal of Veterinary Science, 2016(11), 142-148.

Kawai, K. and Tasaki, T. 2016. Revisiting estimates of municipal solid waste generation per capita and their reliability. Journal of Material Cycles and Waste Management, 18(1), 1-13. https://doi.org/10.1007/s10163-015-0355-1 


\section{INSIGHTS INTO REGIONAL DEVELOPMENT}

ISSN 2669-0195 (online) http://jssidoi.org/jesi/

2021 Volume 3 Number 4 (September)

http://doi.org/10.9770/IRD.2021.3.3(7)

Khan, D., Kumar, A. and Samadder, S. R. 2016. Impact of socioeconomic status on municipal solid waste generation rate. Waste Management, 49, 15-25. https://doi.org/10.1016/j. wasman.2016.01.019

Kyessi, A. G., Omar, H. M. and Saria, J. A. 2017. The influence of economic factor to the sustainability of informal solid waste collection livelihood in urban areas: the case of Kinondoni municipality. Research journalis Journal of Economics, 5(6), 1-17

Maiyaki, M. A., Marzuki, A. and Ahmed, A. A. 2019. Urban solid waste development, a review of Nigeria's waste management policy. International Transaction Journal of Engineering, Management, Applied Sciences and Technologies, 11(5), 1-14. https://doi.org/10.144 56/ITJEMAST.2020.87

Maskey, B. 2018. Determinants of household waste segregation in Gorkha municipality, Nepal. Journal of Sustainable Development, 11(1), 1-12. https://doi.org/10.5539 /jsd.v11n1p1

Mbah, P. O. and Nzeadibe, T. C. 2017. Inclusive municipal solid waste management policy in Nigeria, engaging the informal economy in Post-2015 Development Agenda. Local Environment, 22(2), 203-224.

Merem, E. C., Twumasi, Y., Wesley, J., Isokpehi, P., Fageir1, S., Crisler, M., Romorno, C, Hines, A., Ochai, G. S., Leggett, S. and Nwagboso, E. 2018. Analyzing emerging environmental issues in major areas: the case of Lagos in South-West Nigeria. Architecture Research, 8(1), 19-38. https://doi.org/10.5923/j.arch.20180801.03

Muhammad, Z., Sik, K. K., Johar, F. and Sabri, S. 2016. An overview of critical success factors of public-private partnership in the delivery of urban infrastructure and services. Planning Malays Journal, 16(14), 147-162.

Nabegu, A. B. and Mustapha, A. 2015. Institutional constraints to municipal solid waste management in Kano metropolis, Nigeria. International Journal of Innovative Environmental Studies Research, 3(3), 13-21.

Nabegu, M, A. B. and Naibbi, A. 2017. Environmental regulations in Nigeria: A mini review. International Journal of Environmental Sciences and Natural Resources, 1(5), 4-6. https://doi.org/10.19080/IJESNR.01.555573

Nabukeera, M. 2016. Solid waste management system: Public-private partnership, the best system for developing countries. International Journal of Engineering Research and Applications, 6(4), 57-67

Naibbi, A. I. and Umar, U. M. 2017. An appraisal of spatial distribution of solid waste disposal sites in Kano metropolis, Nigeria. Journal of Geo-science and Environment Protection, 5, 24-36.

Nnaji, C. C. 2015. Status of municipal solid waste generation and disposal in Nigeria. Management of Environmental Quality: An International Journal, 26(1), 53-71.

Obiora, B. E. and Tochukwu, S. E. 2019. Implementation of circular economy principles in industrial solid waste management: case studies from a developing economy (Nigeria). Recycling, 4(42), 1-18. https://doi.org/10.3390/recycling4040042

Odewumi, T. O., Okeniyi, A. G. and Agbede, O. A. 2016. Assessment of solid waste management practices in Ibadan metropolis. Journal of Scientific and Engineering Research, 3(4), 375-382.

Ogunba, A. 2016. An appraisal of the evolution of environmental legislation in Nigeria. Vermont Law Review; 40:673-693.

Ogunjuyigbe, A. S., Ayodele, T. R. and Alao, M. A. 2017. Electricity generation from municipal solid waste in some selected cities of Nigeria: an assessment of feasibility, potential and technologies. Renewable and Sustainable Energy Reviews, 80, $149-162$. https://doi.org/doi.org/10.1016/j.rser.2017.05.177

Ogunniran, B. I. 2019. Harmful effects and management of indiscriminate solid waste disposal on human and its environment in Nigeria: A review. Global Journal of Research and Review, 6(1), 1-4. https://doi.org/10.21767/23938854.100043

Olukanni, D. O. and Aremu, D. O. 2017. Provisional evaluation of composting as priority option for sustainable waste management in South-West Nigeria. Pollution, 2017(3), 417-428. https://doi.org/10.7508/pj.2017.03.007

Olukanni, D. O. and Nwafor, C. O. 2019. Public-private sector involvement in providing efficient solid waste management services in Nigeria. Recycling, 4(19), 1-9. https://doi.org/10.3390/recycling4020019 


\section{INSIGHTS INTO REGIONAL DEVELOPMENT}

ISSN 2669-0195 (online) http://jssidoi.org/jesi/

2021 Volume 3 Number 4 (September)

http://doi.org/10.9770/IRD.2021.3.3(7)

Olukanni, D. O. and Oresanya, O. O. 2018. Progression in waste management processes in Lagos State, Nigeria. IJERA, 18(35), 11-23. https://doi.org/10.4028/www.scientific.net/JERA.35.11

Onuminya, O. T. and Nze, E. C. 2017. An appraisal of waste management in the Lagos metropolis: A case study of Lagos State Waste Management Agency (LASMA). Nigeria Journal of Pure \& Applied Science, 30(3), 3104-3108. https://doi.org/10.19240/njpas.2017.C07

Opoko, A. P. and Oluwatayo, A. A. 2016. Private sector participation in domestic waste management in informal settlements in Lagos, Nigeria. Waste Management \& Research, 34(12), 1217-1223.

Oyedotun, T. D. T., Kasim, O. F., Famewo, A., Oyedotun, T. D., Moonsammy, S., Ally, N. and Renn Moonsammy, D. 2020. Municipal Waste Management in the Era of COVID-19, Perceptions, practices, and potentials for research in developing countries. Research in Globalization, 2(20), 1-10. https://doi.org/10.1016/j.resglo.2020.100033

Popoola, A. A., Ayangbile, O. and Adeleye, B. 2016. Assessment of solid waste management systems in Ibadan North, Oyo State Using Geo-spatial Techniques. Ethiopian Journal of Environmental Studies and Management, 9(6), 666-679.

Rigasa, Y. A., Badamasi, A. G., Galadimawa, N. and Abubakar, G. U. 2016. Community based solid waste management strategy, a case study of Kaduna metropolis. Sustainable Development and Planning, 8,761-772

Rominiyi, O. L., Fapetu, O. P., Owolabi, J. O. and Adaramola, B. A. 2017. Determination of energy content of the municipal solid waste of Ado-Ekiti metropolis, South-West, Nigeria. Current Journal of Applied Science and Technology, 23(1), 1-11. https://doi.org/10.9734/CJAST/217/32340

Salami, H. A., Adegbite, J. O., Bademosi, T. T., Lawal, S.O., Olutayo, O. O. and Olowosokedile, O. 2018. A Review on the current status of municipal solid waste management in Nigeria: Problems and solutions, Journal of Engineering Research and Reports, 3(4), 1-16

Sampson, U. S. and Ojoye, S. 2017. Solid waste disposal and wealth generation in parts of Kaduna metropolis, Nigeria. Journal of Science, Technology, Mathematics and Education (JOSTMED), 13(3)

Sinthumule, N. I. and Mkumbuzi, S. H. 2019. Participation in community-based solid waste management in Nkulumane Suburb, Bulawayo, Zimbabwe. Resources, 8(30), 1-16

Somorin, T. O., Adesola, S. and Kolawole, A. 2017. State-level assessment of the waste-to energy potential (via incineration) of municipal solid wastes in Nigeria. Journal of Cleaner Production, 164(15), 804-815

Song, Q., Li, J. and Zeng, X. 2015. Minimizing the increasing solid waste through zero waste strategy. Journal of Cleaner Production, 104(0), 199-210

Soukopova, J., Struk, M. and Hrebicek, J. 2016. Population age structure and the cost of municipal waste collection. A case study from the Czech Republic. Journal of Environmental Management, 1-9. https://doi.org/10.1016/j.jenvman.2016.03.030

Sridhar, M. K. C., Jegede, A. Oluborode and Uwadiegwu Z. 2017. Waste management policy and implementation in Nigeria. National Journal of Advanced Research, 3 (3), 23-35.

Stanley, H. O. and Owhor, A. C. 2018. Assessment of solid waste management practice in Port Harcourt metropolis, Rivers State, Nigeria. Journal of Geography, Environment and Earth Science International, 16(2), 1-10. https://doi.org/10.9734/JGEESI/2018/42325

Tsunatu, D. Y., Tickson, T. S., Sam, K. D., Namo, J. M. 2015. Municipal solid waste as alternative source of energy generation: a case study of Jalingo metropolis, Taraba State Nigeria. International Journal of Engineering and Technology, 5(3).

Winter, M. and Ujoh, F, 2020. A review of institutional frameworks and financing arrangements for waste management in Nigerian cities. Urban Studies and Public Administration, 3(2), 21-68. 
INSIGHTS INTO REGIONAL DEVELOPMENT

ISSN 2669-0195 (online) http://jssidoi.org/jesi/ 2021 Volume 3 Number 4 (September) http://doi.org/10.9770/IRD.2021.3.3(7)

Sunday FAKUNLE holds the post of Teaching Assistant at Department of Behavioural Studies, Redeemer's University, Nigeria. With substantial progress, he is currently doing his PhD in Sociology and Anthropology, specializing in Public health, Social Change and Development in African Communities, in Obafemi Awolowo University, Nigeria. He worked as an online Sociology instructor in OAU Centre for Distance Learning, Nigeria.

ORCID ID: orcid.org/0000-0002-0053-0082

Oludele AJANI is a Professor of Social Change and Development. As of July 2021, he is concurrently the Vice Dean of the Faculty of Social Sciences and the Head of Department of Sociology and Anthropology, Obafemi Awolowo University, Nigeria. He has also immensely contributed to the field of gender studies and industrial sociology and a series of international and national academic journals as the chief editor and contributor.

ORCID ID: orcid.org/0000-0001-9392-5587

Make your research more visible, join the Twitter account of INSIGHTS INTO REGIONAL DEVELOPMENT:

@IntoInsights

Copyright (C) 2021 by author(s) and VsI Entrepreneurship and Sustainability Center

This work is licensed under the Creative Commons Attribution International License (CC BY).

http://creativecommons.org/licenses/by/4.0/

c) (i) Open Access 